$\$=-$ 国

\title{
Empirical investigation of indoor environmental quality (IEQ) in a hospital building in Merida Yucatan, Mexico
}

\author{
Fanny C. Cocom Martínez ${ }^{1 *}$ \\ ${ }^{I}$ National Autonomous University of Mexico, Mexico City, Mexico \\ *Corresponding author E-mail: facocom@comunidad.unam.mx
}

\begin{abstract}
This research summarizes the result of physical measurement of the indoor environmental quality (IEQ) in two different hospital rooms, from a small hospital in Merida Yucatan, Mexico. The results show wide differences in the established parameters for this evaluation and the measures obtained. The temperature levels exceed the range of $20-26^{\circ} \mathrm{C}$ in both rooms, considering that bothrooms have air conditioning system (ISO 7730, 2005). The levels of Relative Humidity also exceed in more than $20 \%$ of the permitted range. The amount of $\mathrm{CO}_{2}$ is registered in higher levels when the air conditioning system is on, this is due to the lack of circulation and proper ventilation (ASHRAE 62.1, 2016). About Light Intensity showing the difference between rooms, is represented in the obtained results in the established parameters and their physical characteristics (NOM-025-STPS, 2008). Optimum conditions in indoor environments should result in health, wellbeing and comfort, both in terms of working life and in the areas where healthcare is concerned. The current society demands safe, clean and well-conditioned places, for which it is necessary to integrate perceptions and demands of the users to reach an optimal balance between social and legislative standards.
\end{abstract}

Keywords: Environmental Quality, Evaluation, Healthcare facility, Indoor, Measurement.

\section{Introduction}

Indoor Environmental Quality (IEQ) refers to the quality of a building's environment in relation to the health and well-being of those who occupy space within it. It is one of the considerations for green building ratings like LEED and BREEAM, some of the national and international certifications which promotes a healthier and safer environment, is determined by many factors.

An environment that contributes to heal, not only adds to the wellbeing of the patient, but also to the well-being of the hospital's medical and support staff. A hospital with a good IEQ promotes health in their spaces, as well as the efficiency of their workers.

The follow-up to a IEQ evaluation in hospital buildings, has the task to draw the attention of professional designers and policy makers towards green / healthy building initiatives. In Mexico IEQ evaluations are applied to offices and classrooms, so highlighting the need for this kind of assessments in hospitals, is of great importance for continuous improvement.

Authors [1] said that the perception of satisfactory IEQ (satisfactory comfort conditions and air quality) reduces the average number of health complaints and symptoms per person and improves working conditions. This proves the importance of continuous monitoring of the indoor environment.

As architects, we have this important task of research to improve spaces, specifically in hospitals, at the same time considering the needs of the users, but these sometimes come in different ways and answers. For example, the requirements imposed by standards often lead to dissatisfaction for the users: in the Survey Evaluation of the IEQ in a Large Romanian Hospital, some of the medical staff demand for low temperatures, others feel discomfort and often pa- tients due to their health conditions can not regulate their temperature, having problems finding the optimal thermal conditions [2]. In this research, the author tries to focus on the principal users of a hospital, and the patient is considered as target for future evaluations, including their feedback from the spaces they use. An international example is The Global Green and Healthy Hospitals, their members are using innovation, ingenuity, and investment to transform the health sector and foster a healthy future for people and the planet [3]. Mexico has 33 public hospitals throughout the country that are members of this network. One of the sectors with the lowest infrastructure budget is specifically in Mexico. Here lies the importance of applying this type of evaluation in the author's country.

\section{Methods}

The evaluation in the study case is based on two assessment methods of the physical environment, which was developed by an international certification: The Well Building Standard made by the International Well Building Institute, based on international standards. This is the first standard of its kind that focuses solely on the health and wellness of building occupants. The second assessment is NMX-AA-162-SCFI-2012 [4], the National Environmental Audit Program from PROFEPA (acronym in Spanish), a national governmental office that wants to increase levels of compliance with environmental regulations in Mexico. The applied method was modified to meet certain hospital requirements. With five general steps of the evaluation, 1. Request, 2. Information Gathering, 3. Measurement, 4. Results and Discussion and 5. Recommendations. For this empirical evaluation, the author only focused on steps 2,3 and 4. Considering the parameters in the 3 variables of air, light and comfort, based on The Well Building Standard [5]. 
The selection of the months for the measurementwere taken based on the maximum monthly records of outdoor temperature in 2016. [6]. The duration of the measurement was established by the administration of the hospital. The measurement was obtained during two different seasons in the same case study. The first period was from December-30-2016 to January-06-2017 (winter) which took place in two different rooms in the hospitalization area, the second period was for nine days from July 17 to July 25 of 2017 (summer) in the same rooms. In order to capture the measures in the IEQ parameters and compare between the different rooms and seasons measures in winter and summer were performed during the following dates as shown in Table 1, for each room of this study case.

\begin{tabular}{|c|c|c|}
\hline Room & Winter & Summer \\
\hline 01 & $\begin{array}{c}\text { December } 302016 \\
\text { to } \\
\text { January } 032017\end{array}$ & $\begin{array}{c}\text { July } 212017 \\
\text { to } \\
\text { July } 252017\end{array}$ \\
\hline 03 & $\begin{array}{c}\text { January } 032017 \\
\text { to } \\
\text { January } 062017\end{array}$ & $\begin{array}{c}\text { July } 172017 \\
\text { to } \\
\text { July } 212017\end{array}$ \\
\hline
\end{tabular}

Table 2: Description of the mobile instruments used for the measurement.

\begin{tabular}{|c|c|c|c|c|}
\hline Variable & $\begin{array}{c}\text { Instrument } \\
\text { Model }\end{array}$ & Resolution & Range & Accuracy \\
\hline $\begin{array}{c}\text { Air } \\
\text { Tempera- } \\
\text { ture }\end{array}$ & \multirow{3}{*}{$\begin{array}{c}\text { HOBO } \\
\text { Data log- } \\
\text { ger } \\
\text { U12-012 }\end{array}$} & $\begin{array}{c}0.03^{\circ} \mathrm{C} @ \\
25^{\circ} \mathrm{C}\end{array}$ & $\begin{array}{c}-20^{\circ} \mathrm{C}- \\
70^{\circ} \mathrm{C}\end{array}$ & $\pm 0.35^{\circ} \mathrm{C}$ \\
\hline $\begin{array}{l}\text { Relative } \\
\text { Humidity }\end{array}$ & & $0.03 \%$ & $5 \%-95 \%$ & $\pm 2.5 \%$ \\
\hline $\begin{array}{c}\text { Light } \\
\text { Intensity }\end{array}$ & & & $1-3000$ & Manually \\
\hline \multirow{2}{*}{$\begin{array}{l}\text { Carbon } \\
\text { dioxide }\end{array}$} & $\begin{array}{c}\text { HOBO } \\
\text { MX1102 }\end{array}$ & $1 \mathrm{ppm}$ & $\begin{array}{c}\text { Oppm - } \\
\text { 5000ppm }\end{array}$ & $\begin{array}{c} \pm 50 \mathrm{ppm} \\
\pm 5 \%\end{array}$ \\
\hline & $\begin{array}{c}\text { Telaire } \\
7001\end{array}$ & $\pm 1 \mathrm{ppm}$ & $\begin{array}{c}0-10000 \\
\text { ppm }\end{array}$ & $\begin{array}{c} \pm 50 \mathrm{ppm} \\
\pm 5 \%\end{array}$ \\
\hline
\end{tabular}

The data was collected continually every minute, while the room was occupied. The measuring instrument is conducted at the bed patient's location at $1.80 \mathrm{~m}$ above level floor as shown in Figure 1, 2,3 and 4 . The instruments used for the measurement are described in Table 2.

Every time it is restarted, a Hobo Data logger U12-012, measures air temperature, relative humidity and light intensity, the calibration of this equipment is automatic,. The HOBO MX1102 measures carbon dioxide, air temperature and relative humidity, for this particular evaluation, only the carbon dioxide data is considered. Telaire 7001 sensor, measures carbon dioxide and temperature, can calculate and display real-time ventilation rates. The calibration for the Carbon Dioxide instruments need to be done manually or automatically, but considering the elevation above the sea level from de site.

This evaluation investigates the IEQ in two rooms from a second level hospital, and from the private sector health institute for charity (Red Cross) in Mexico. This is a hospital that is against cancer. It was selected based on the conditions of the building and the high demand of the services for this type of disease. It is located in Merida, the capital city of the state of Yucatan southeast of Mexico. It is found on the latitude $21^{\circ} 01^{\prime} 19^{\prime \prime} \mathrm{N}$ and longitude $89^{\circ} 37^{\prime} 36^{\prime \prime} \mathrm{W}$ at $19.68 \mathrm{ft}(6 \mathrm{~m})$ above sea level [6]. Merida has a climate condition different from other regions in the country, having an average temperature of $27.1^{\circ} \mathrm{C}$ in the 2016 , reaching last year at $39.4^{\circ} \mathrm{C}$ as $\max -$ imum temperature reached in May and the lowest at $13.6^{\circ} \mathrm{C}$ in February. According to the National Institute of Statistic and Geography in Mexico the mean annual precipitation in the state is $1100 \mathrm{~mm}$ and it is considered a sub humid warm climate [7].

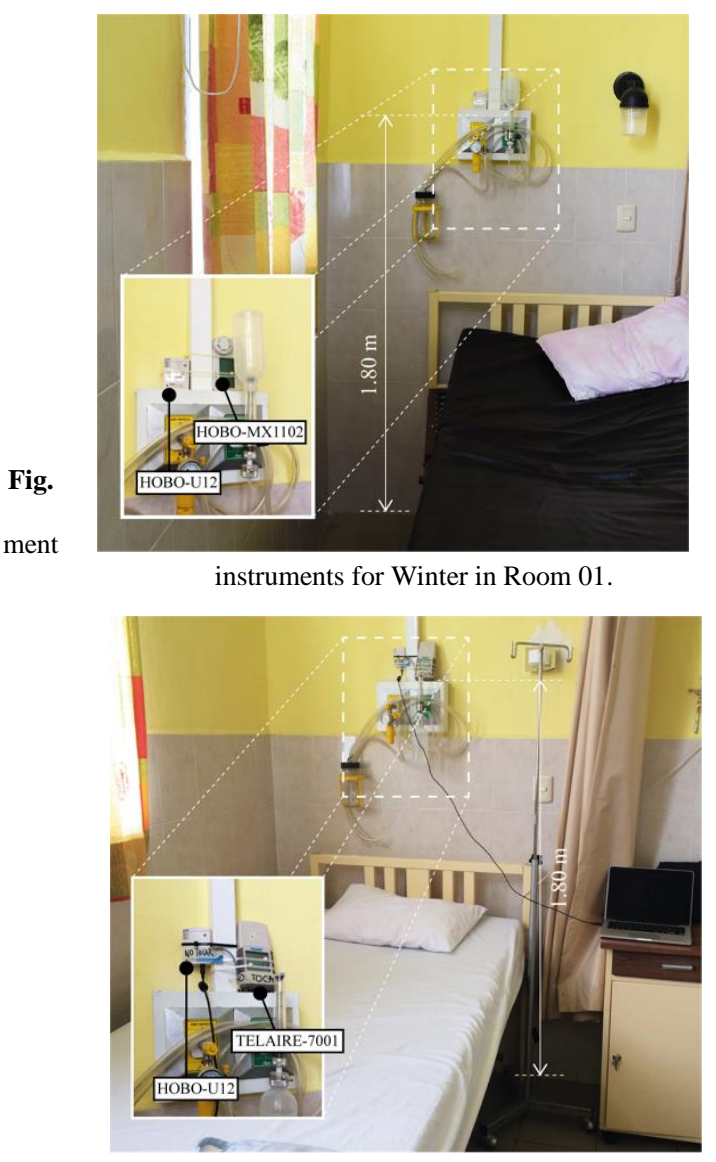

Fig. 2: Measurement instruments for Summer in Room 01.

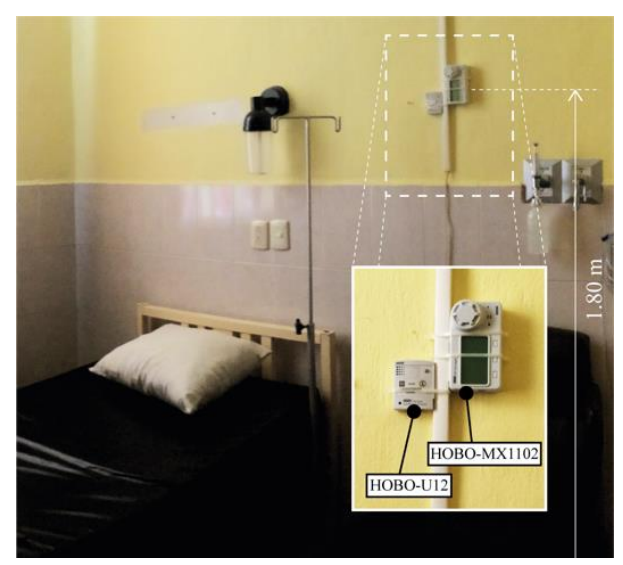

Fig. 3: Measurement instruments for Winter in Room 03.

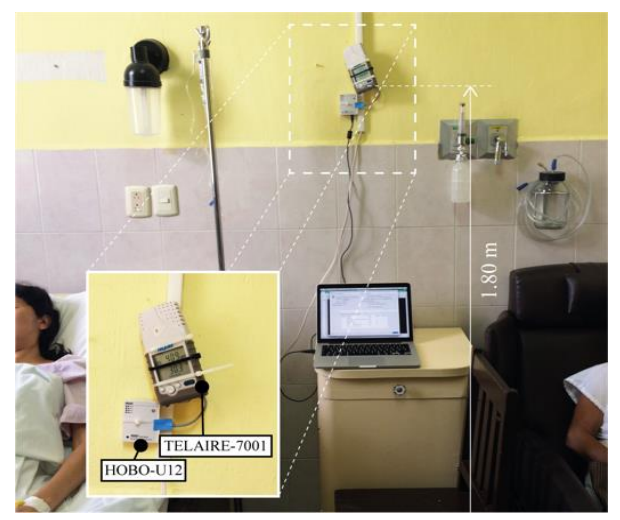

Fig. 4: Measurement instruments for Summer in Room 03.
1:

Measure- 
The case study has a capacity of five rooms designated for ambulatory and post operatory hospitalization, with services of treatment for cancer like radiation, chemotherapy and operating room. The building has a historic importance, because it was built from 1943 to 1945 and was inaugurated in 1946, one of its kind in the region at the time. This is found inFigure 5 and Figure 6 . The formal characteristics of the building can be appreciated.

The hallway of the hospitalization ward area is both, naturally and mechanically ventilated with ceiling fans. The natural ventilation occurs through windows facing north and west, allowing for cross ventilation. A local construction feature presented in the building, which influences IEQ is the building material of the walls. Masonry makes thermal insulation from the high outside temperatures.

Room 01 and 03 are both, naturally and mechanically ventilated, and also, with split-level air-conditioning system. Differences in the quantity of windows are represented in the different measures of the quality of light intensity. In Figure 7 are represented these features.

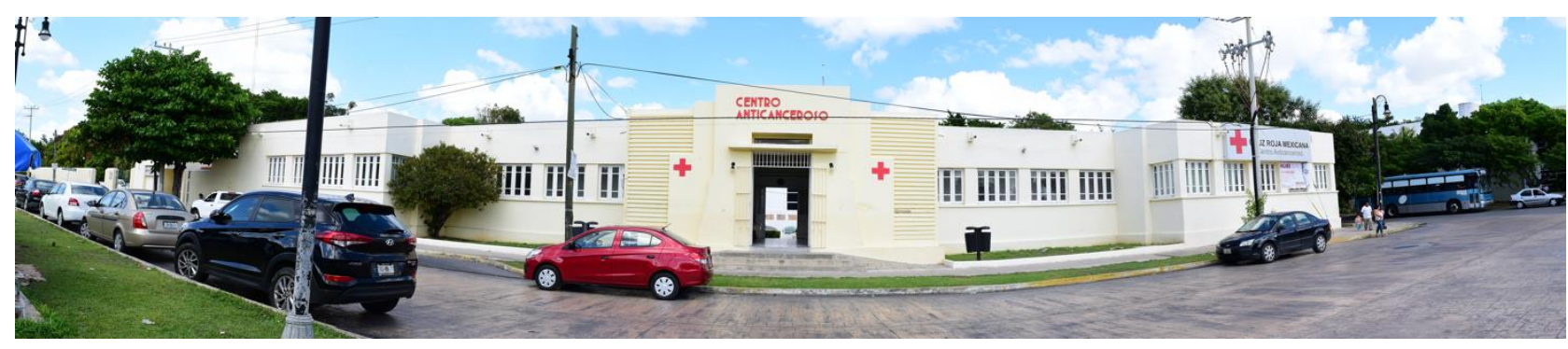

Fig. 5: Main facade of the building.

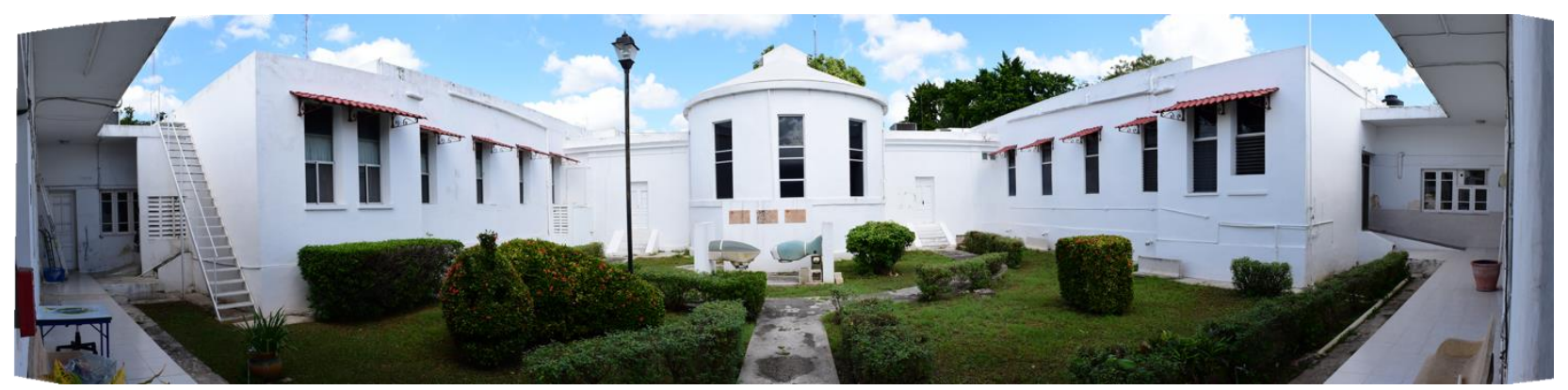

Fig. 6: View to the interior garden.

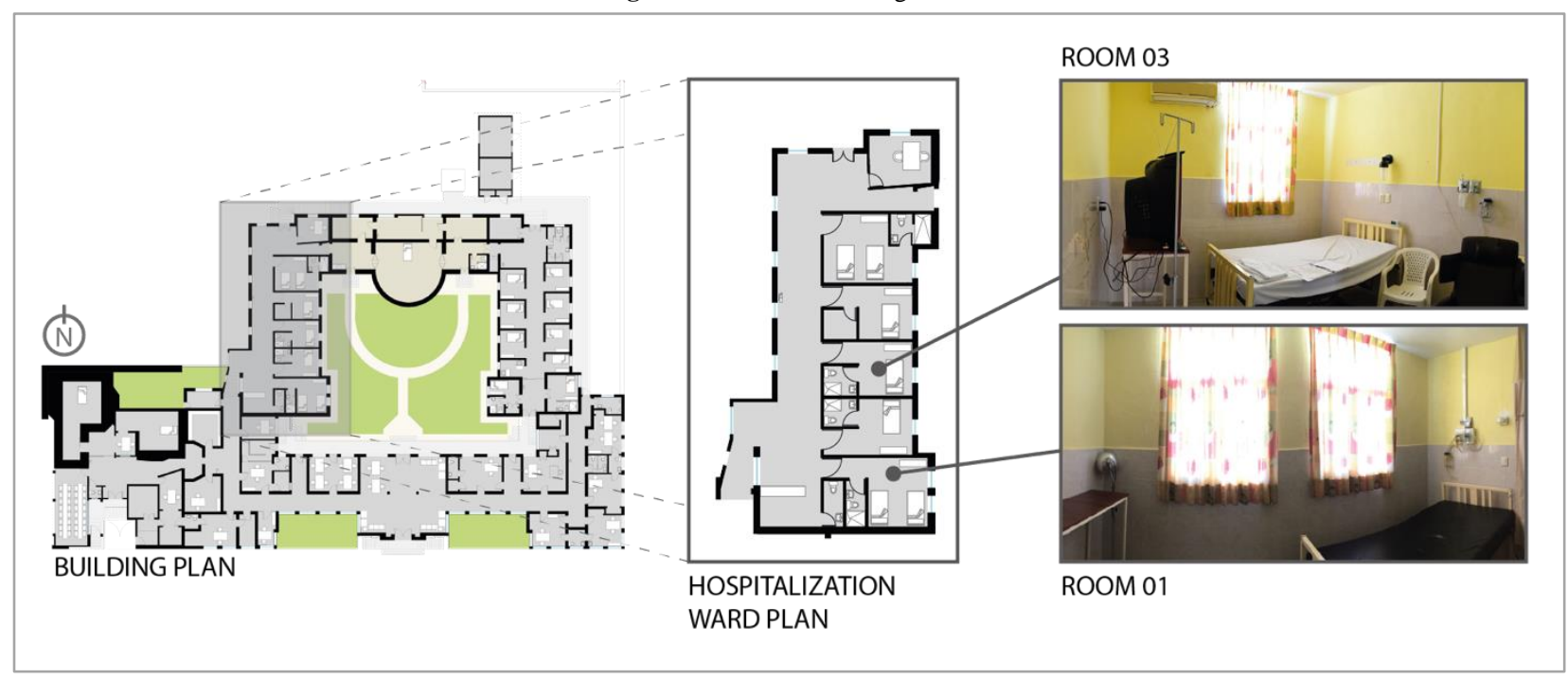

Fig. 7: Architectural features of the building, orientation and spaces evaluated.

\section{Results and Discussion}

According to the UNE-171330-1:2008 [8] the Indoor Environmental Quality (IEQ) is defined as the indoor environmental conditions, appropriate to the user and his activities, defined by levels of chemical and microbiological contamination, and by the values of the physical factors. For the case of this empirical investigation, it will focus on the physical factors.

\subsection{Thermal Comfort Quality}

Considered a primary factor for comfort and health of the patient. The thermal comfort is measured by indoor temperature and relative humidity. Based on ISO 7730:2005 the parameters considered are $22^{\circ} \mathrm{C} \pm 2^{\circ} \mathrm{C}$ for winter and $24.5^{\circ} \mathrm{C} \pm 1.5^{\circ} \mathrm{C}$ for summer. The results obtained in the rooms are represented in the Figure 8. The recorded mean temperature in Room $01\left(25.59^{\circ} \mathrm{C}\right)$ and Room $03\left(25.06^{\circ} \mathrm{C}\right)$ in winter is between parameters, but it does not apply in the mean temperature in the summer as it is above $2.4^{\circ} \mathrm{C}$ in Room 01 and $0.92^{\circ} \mathrm{C}$ in Room 03 from the maximum permitted. Inclusive of the maximum temperature in both rooms which shows more than $4^{\circ} \mathrm{C}$ from the limit permitted for the comfort of the patient. The differences between them show minimum changes in the temperature. 
In the case of the humidity control, it is essential for achieving a level of comfort that guarantees working efficiently and quality of life in hospitals. Analysis of building structures also takes into account occupant comfort: this aspect is even more important in hospitals, where there are patients, visitors and healthcare workers at risk of infection due to germs, bacteria and viruses. The right humidity reduces airborne proliferation and propagation of pathogens, making the environment safer. The WELL Building Standard (2017) requires maintaining relative humidity between $30 \%$ to $50 \%$ at all times. The results shown in Figure 9, the maximum registered in Room 01 is $27.79 \%$ which is above the parameter, in Room 03 the difference is bigger $32.12 \%$. We need to consider the location, the type of building and materials because this can cause, big differences to keep a healthy environment thereby causing more health problems on the patients inside the rooms.

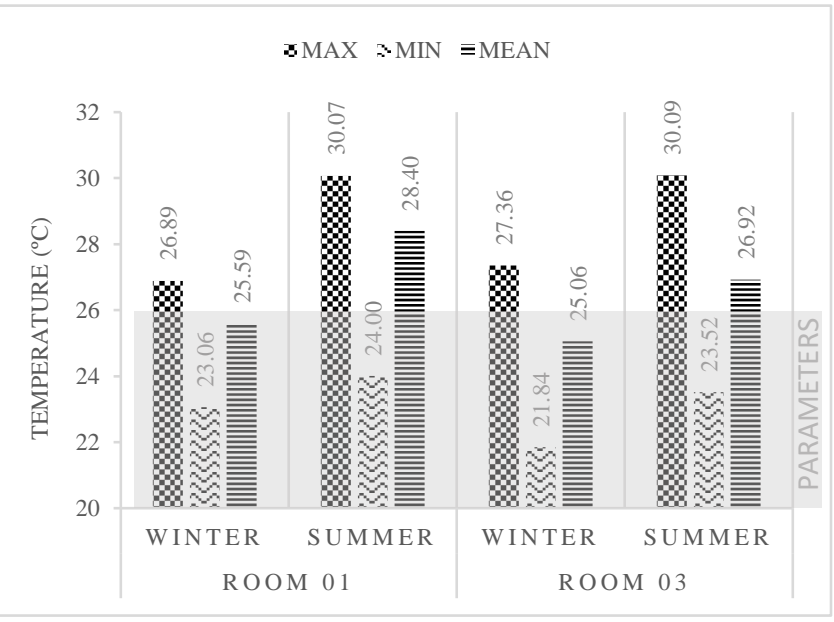

Fig. 8: Periodic results for Room 01 and Room 03 in both seasons. Indoor temperature $\mathrm{MIN}=$ minimum $, \mathrm{MAX}=\operatorname{maximum},{ }^{\circ} \mathrm{C}=$ Centigrade

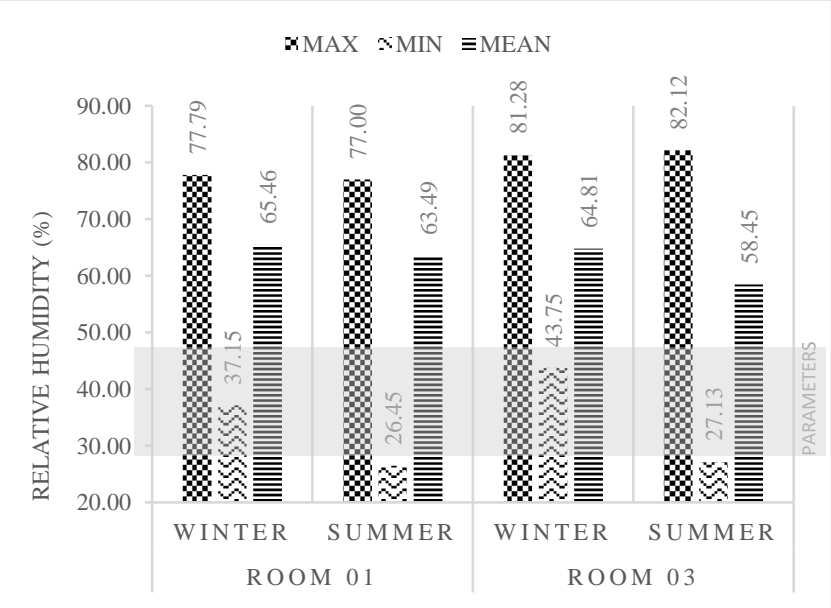

Fig. 9: Periodic results for Room 01 and Room 03 in both seasons. Indoor relative humidity. $\mathrm{MIN}=$ minimum, $\mathrm{MAX}=$ maximum

\subsection{Light Intensity Quality}

Based on the type of activity performed and the user performing it, it is considered as follows and according to the Mexican Standard NOM-025-STPS-2008 [9]. Table 3

Table 3: Parameters considered for the amount of light intensity, according to the activity performed.

\begin{tabular}{c|cc}
\hline User & Activity & Parameter \\
\hline \multirow{2}{*}{ Patient } & Simple visual requirement & $200 \mathrm{lux}$ \\
& Reading & $300 \mathrm{lux}$ \\
\hline \multirow{2}{*}{ Physician } & High accuracy, detail distinction & $1000 \mathrm{lux}$ \\
& Surveillance & $50 \mathrm{lux}$ \\
\hline
\end{tabular}

The variations in light intensity levels are shown in Figure 10. The highest recorded was 1289 lux on the summer season in the room 01 , having a big difference between room 03 which had at maximum 705.60 lux in winter season. In the case of room 03 it never reaches the optimal conditions of lighting, during the continuous measurement in both seasons.

Having similar architectural features, we can see the big difference between a room with one (room 03) and two (room 01) windows. The difference reaches 583.40 lux in its maximum measures recorded.

Although measures registered are smaller than 50 lux, this is considered a good feature of total darkness for the tranquility of the patient [10].

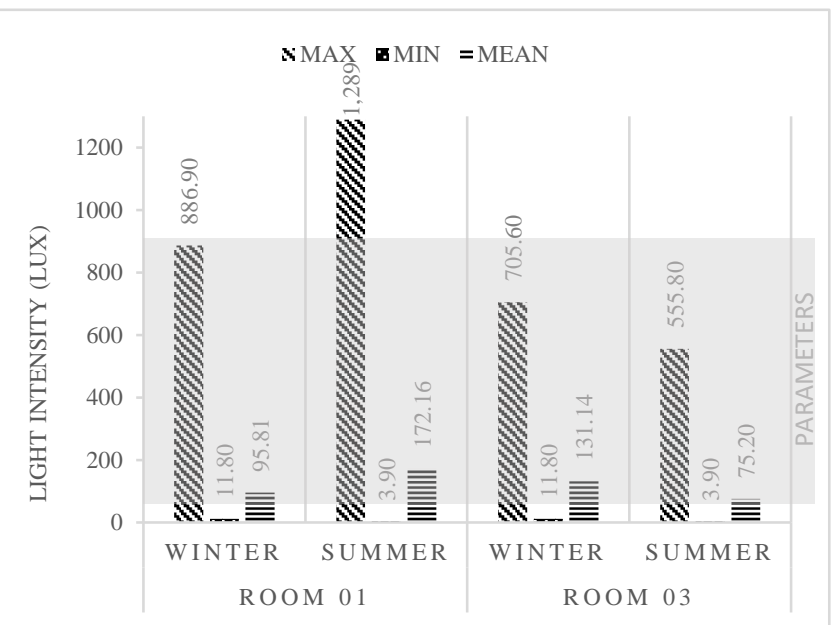

Fig. 10: Results $M I N=$ minimum, $M A X=$ maximum and mean of light intensity levels.

\subsection{Indoor Air Quality}

Levels of $\mathrm{CO}_{2}$ are not considered in different standards as pollutants, but being present in excessive levels in some spaces, is considered for the comfort of the user's space, ASHRAE 62.1-2016 [11] tells us that indoor $\mathrm{CO}_{2}$ concentrations of 1000 to $1200 \mathrm{ppm}$ (parts-per-million, $10^{-6}$ ) in spaces for sedentary activities, is an indicator that a substantial majority of visitors entering the space will be satisfied. The Figure 11 shows the results of the measurement, in this case the higher number was obtained in Room 03 with 2,975 ppm, which showed more than double the amount considered as optimal comfort. The lack of cross ventilation could have been the result of the higher level of $\mathrm{CO}_{2}$ concentration recorded

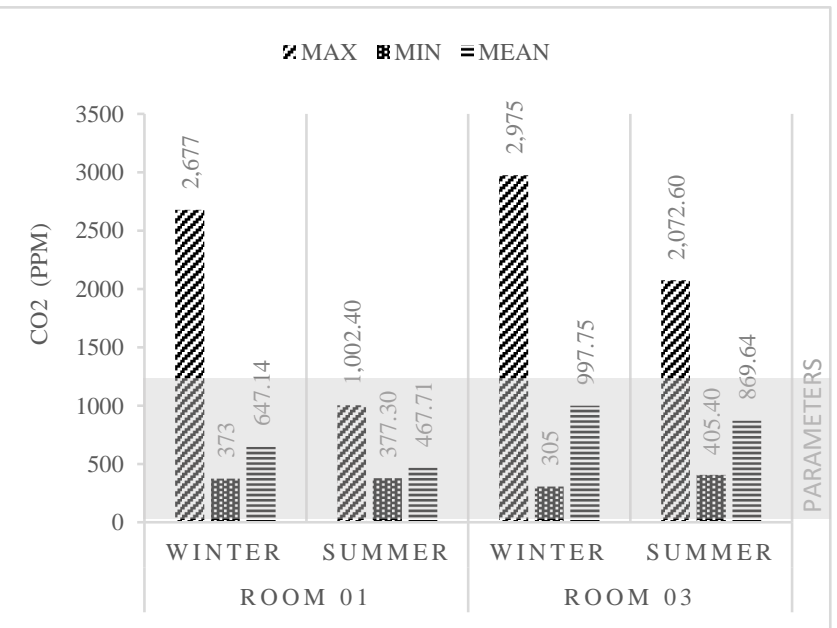

Fig. 11: Results minimum, maximum and mean of $\mathrm{CO} 2=$ Carbon Dioxide levels. $\mathrm{MIN}=$ minimum, $\mathrm{MAX}=$ maximum 


\subsection{Comparative rooms and seasons}

In Figure 12 and 13 the differences between the mean values measured in each room can be appreciated. The room 03 presents the higher values in $\mathrm{CO}_{2}$ levels. The data is integrated as an abstract, to compare the small differences in the other variables.

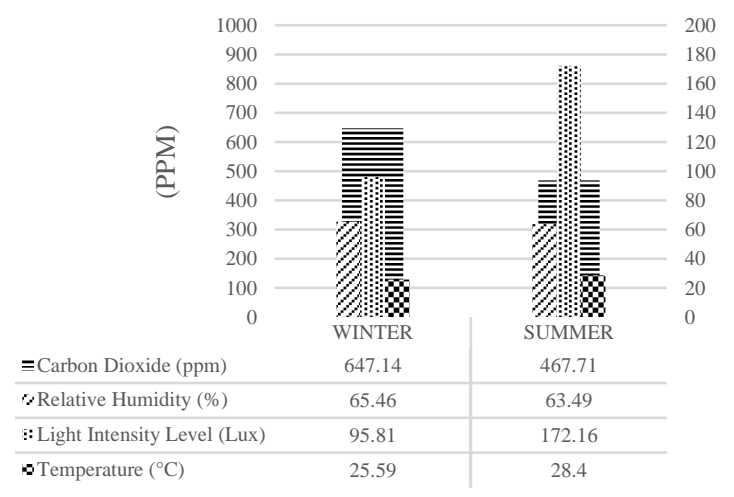

Fig. 12: Mean values of measured indoor variables in Room 01. PPM=partsper-million, $10^{-6},{ }^{\circ} \mathrm{C}=$ Centigrade

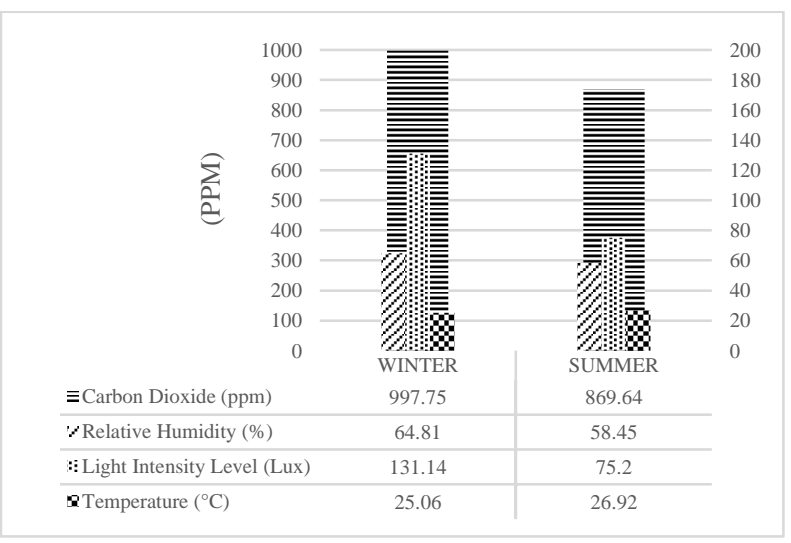

Fig. 13: Mean values of measured indoor variables in Room 03. PPM=partsper-million, $10^{-6},{ }^{\circ} \mathrm{C}=$ Centigrade

\section{Conclusion}

The obtained data represents, the information needed to make recommendations and make improvements. Specially in Mexico, the need of this evaluation will bring in new information of the actual state of the infrastructure for health. If it is applied to different case studies, the author can compare and develop a specific method for every region in the country.

Optimum IEQ conditions generate beneficial effects on health, not only by controlling pollutants but also by improving ergonomic and psychological conditions.

Monitoring the indoor air quality, allows individuals to be aware of and promptly fix any deviations in indoor quality metrics. This will limit the growth of pathogens and maintain thermal comfort by providing the appropriate level of humidity.

Proximity to windows, outdoor views and daylight in indoor spaces are some of the most important element of the design. This is by promoting exposure to daylight and views of varying distances from the room. Thereby supporting psychological health by setting thresholds for indoor sunlight exposure.

The suggestion after this investigation is the need for a correct design to allow cross ventilation in all the indoor spaces. This is done by trying to enhance the strategies to transform this spaces for health, having in mind the comfort and needs from the users and their health problems.
The current state of IEQ should be considered as the main priority for the correct design and use of space. Since, based on new research, we now know that the relation of space and the physiological health of its occupant are closely related.

Considering as environmental health, the quality of the interior space produces a positive response both emotional and physical for the user.

It seeks to open the multidisciplinary and transdisciplinary panorama, in the analysis of the quality of the interior environment. This would include aspects of evaluations of physical and psychological parameters within the environmental analysis, to ensure or check environmental health.

It is evident that to include more variables to this evaluation is highly recommended in order to get more information. But the lack of measurement equipment is an important limitation, as well as the particular specifications of the administration in the case study.

\section{Acknowledgement}

The author acknowledges the interest of the anticancerous hospital from the Red Cross in Merida Yucatan Mexico, for performing this research and the permits granted to enable work carried out within the facilities. She also wants to acknowledge the opportunity given from Alejandra González Pino, to work together with the staff and the patients at her service.

Not forgetting to thank the National Council for Science and Technology in Mexico (CONACYT acronym in Spanish) for funding this research. And National Autonomous University of Mexico (UNAM acronym in Spanish) for allowing this investigation to be carried out.

\section{References}

[1] Dascalaki E., Gaglia A., Balaras C., \& Lagoudi A. "Indoor environmental quality in Hellenic hospital operating rooms". Energy and Buildings, Vol.41, No.5, (2009). pp.551-560. available online: http://dx.doi.org/10.1016/j.enbuild.2008.11.023

[2] Croitoru, C., Vartires, A., Bode, F., \& Dogeanu, A. "Survey Evaluation of the Indoor Environment Quality in a Large Romanian Hospital”. INCAS BULLETIN, Vol.5, No.3, (2013). pp. 45-52. available online: http://dx.doi.org/10.13111/2066-8201.2013.5.3.5

[3] Global Green and Healthy Hospitals. (2017). Greenhospitals.net. Last visit:14.09.2017, available online: https://www.greenhospitals.net

[4] NMX-AA-162-SCFI-2012. “Auditoría Ambiental, Metodología para realizar auditorías y diagnósticos, ambientales". PROFEPA. (2013) Last visit: 08.04.2018, available online: http://www.ens.uabc.mx/documentos/NMX-AA-162-SCFI2012_DOF_02-10-2013.pdf

[5] WELL Building Standard. (2017). International WELL Building Institute. Last visit:14.09.2017, available online: https://www.wellcertified.com/en

[6] CINVESTAV. (2017). Mda.cinvestav.mx. Last visit: 12.09.2017, available online: http://www.mda.cinvestav.mx/weather/NOAAPRYR.TXT

[7] INEGI (2017).Instituto Nacional de Estadística y Geografía. available online: http://www.inegi.org.mx

[8] UNE 171330-1:2008.(2008) Calidad del Ambiente Interior. Instituto Nacional de Seguridad e Higiene en el Trabajo. Centro Nacional de Nuevas Tecnologías. Madrid España.

[9] NOM-025-STPS-2008. (2008) Norma Oficial Mexicana, Condiciones de iluminación en los centros de trabajo.

[10] Bernhofer, E., Higgins, P., Daly, B., Burant, C., \& Hornick, T. "Hospital lighting and its association with sleep, mood and pain in medical inpatients". Journal Of Advanced Nursing, Vol.70, No.5, (2013). pp 1164-1173. available online: http://dx.doi.org/10.1111/jan.12282

[11] ASHRAE 62.1-2016. (2016) Ventilation for acceptable indoor air quality. American Society of Heating, Refrigerating and Air-conditioning Engineering. Atlanta USA. 